\title{
Evaluation of the Antibiotic Use for Surgical Prophylaxis in Paediatric Acute Appendicitis
}

\author{
Inese Sviestina ${ }^{1,2^{*}}$, Dzintars Mozgis ${ }^{3}$ \\ ${ }^{1}$ University Children's Hospital Vienibas gatve 45, Riga, Latvia \\ ${ }^{2}$ Faculty of Pharmacy Riga Stradinš University, Dzirciema iela 16, Riga, Latvia \\ ${ }^{3}$ Public Health and Epidemiology Department, Riga Stradinš University, Dzirciema iela 16, Riga, Latvia.
}

\begin{abstract}
Introduction: The aim was to evaluate antibiotic use for surgical prophylaxis in paediatric acute appendicitis before and after introduction of the hospital guidelines. Materials and Methods: Retrospective - observational study of antibiotic use in 68 patients with acute appendicitis in the Paediatric Surgery clinic at the University Children Hospital. Duration of this study was four months: July/August and November/December 2013. All data, such as patients' demographic details, information on antibiotic use and surgery, were collected from the patients' medical records. Results: Total number of patients: 30 in July/August and 38 in November/December. Surgery had 28 (93.3\%) patients in July/August, $33(86.8 \%)$ in November/ December. 2 patients in July/August and 5 in November/December were treated with ampicillin and gentamicin. 2 (8.7\%) patients received a single dose in July/August, $4(12.9 \%)$ in November/December; receiving multiple doses within $24 \mathrm{~h}: 1$ (4.3\%) patient in July/August, 2 (6.5\%) in November/December; prophylaxis >1 day: 20 (87\%) patients in July/August, 25 $(80.6 \%)$ in November/December. Prophylaxis was too early in 7 (30.4\%) patients in July/August, $9(29 \%)$ in November/ December; on time: $2(8.7 \%)$ in July/August and $8(25.8 \%)$ in November/December, too late: $12(25.2 \%)$ in July/August, $14(45.2 \%)$ in November/December. One (3.2\%) patient in November/December received antibiotics in accordance with the guidelines. Conclusion: Although the guidelines were discussed and accepted by surgeons and there was two month introduction period as well, only few positive trends were observed with the antibiotic treatment guidelines not having major impact on antibiotic use. There is a need for new ways of promoting adherence to the guidelines and appropriate antibiotic use.

Key words: Acute appendicitis, antibiotic guidelines, hospitalized children, surgical prophylaxis.
\end{abstract}

\section{INTRODUCTION}

Acute appendicitis is one of the most common reasons for surgery. According to some data the incidence of

\begin{tabular}{|c|c|}
\hline \multicolumn{2}{|c|}{ Access this article online } \\
\hline Journal Sponsor & \multirow[b]{2}{*}{$\begin{array}{l}\text { Website: } \\
\text { www.jyoungpharm.org }\end{array}$} \\
\hline \multirow{2}{*}{ www.phcog net } & \\
\hline & $\begin{array}{l}\text { DOI: } \\
\text { 10.5530/jyp.2015.1.3 }\end{array}$ \\
\hline
\end{tabular}

appendicitis is 100 out of 100000 people annually with accumulative life risk at $7 \%{ }^{1}$ but in the case of perforated appendicitis the incidence is 20 out of 100000 people. $^{2}$ Appendicitis is also among the most common reasons for surgery in children and adolescents with the highest prevalence in 10-19 years old., ${ }^{2,3}$ Antibiotics are among the most common medicines given to children. ${ }^{4}$ According to some studies, during their hospital stay $60 \%$ of the children receive at least one antibiotic. ${ }^{5}$ To improve this situation the Council of the European Union has proposed to "develop strategies for the prevention of infections and the containment of resistant pathogens". ${ }^{6}$

*Address for correspondence:

Inese Sviestina, University Children's Hospital Vienibas gatve 45, Riga, Latvia, Faculty of Pharmacy Riga Stradinš University, Dzirciema iela 16, Riga, Latvia, E Mail: inese.sviestina@gmail.com 


\begin{tabular}{lll}
\hline \multicolumn{2}{l}{ Table 1: Patients' demographic data } \\
\hline $\begin{array}{l}\text { Patients' } \\
\text { demographic } \\
\text { characteristics }\end{array}$ & July/August & $\begin{array}{l}\text { November/ } \\
\text { December }\end{array}$ \\
\hline & $\begin{array}{l}\text { No of patients (\%) } \\
{[95 \% \mathrm{Cl}]}\end{array}$ & $\begin{array}{l}\text { No of patients }(\%) \\
{[95 \% \text { Cl] }}\end{array}$ \\
\hline $\begin{array}{l}\text { Total N of patients with } \\
\text { acute appendicitis }\end{array}$ & 30 & 38 \\
$\begin{array}{l}\text { Patients who had } \\
\text { surgery }\end{array}$ & $28(93.3)[78.7-98.2]$ & $33(86.8)[72.7-94.2]$ \\
Age range & & \\
$>5$ years $\leq 12$ years & $18(60.0)$ & $21(55.3)$ \\
$>12$ years $\leq 18$ years & $12(40.0)$ & $17(44.7)$ \\
Gender & $22(73.3)$ & $21(55.3)$ \\
Male & $8(26.7)$ & $17(44.7)$ \\
\hline \begin{tabular}{l} 
Female \\
\hline
\end{tabular}
\end{tabular}

Antimicrobial surgical prophylaxis occurs in one third of all antibiotic use in paediatric hospitals and $80 \%$ of all antibiotic use in surgery. Different studies underline that antimicrobial surgical prophylaxis is often prolonged unnecessary and contradicts with local or international guidelines. ${ }^{7-9}$ There is an urgent need to change the prescribing practice for children in general and surgical prophylaxis in particular through improved antimicrobial stewardship and identification of the factors, which have the biggest influence on antimicrobial prescribing. ${ }^{10,11}$ The main goal of this study was to evaluate antibiotic use for surgical prophylaxis in paediatric acute appendicitis before and after the introduction of the hospital guidelines.

\section{MATERIALS AND METHODS}

This was a retrospective descriptive study. The University Children's Hospital in Riga, Latvia is the only paediatric hospital in the country with approximately 400 beds. Hospital hosts a range of specialities including Cardiology, Endocrinology, General Paediatrics, General Surgery, Haematology, Hepatology, Neurology, Nephrology, Oncology and also has paediatric and neonatal intensive care units. The study period was $1^{\text {st }}$ July $-31^{\text {st }}$ August (a period before the introduction of the hospital guidelines) and $1^{\text {st }}$ November $-31^{\text {st }}$ December (a period after the introduction of the hospital guidelines). Antibiotic prophylaxis guidelines were officially accepted by the hospital general board at the beginning of September. September and October were considered as a transition period for the introduction of the guidelines. All data were collected by a clinical pharmacist from the medication charts, the patients' medical notes, anaesthetic and nursing records. The following data were collected: demographic details including gender, age and weight, prescribed antibiotic(s), dose, frequency, route of administration, length of operation, time of incision, and timing of the first dose before incision. Prophylaxis was considered as appropriate: "on time" - if the antimicrobial agent was started within 60 minutes before surgical incision, "too late" - if started during or after appendectomy, "too early" - if started more than 60 minutes before incision. If more than one antibiotic was prescribed for a prophylaxis all parameters were evaluated for each drug separately. All inpatients under 18 with diagnosis "acute appendicitis" were included in the study. Main outcome measures: comparative analysis of the appropriateness of prophylaxis: number and percentage of patients, who got prophylaxis on time, correct antibiotic choice and duration of prophylaxis. Data were analysed using the SPSS 20.0 software package. Patients' characteristics were analyzed using descriptive statistics (mean $\pm \mathrm{SD}$ (age), kurtosis, skewness and percentages of patients in each age group and patients receiving antibiotics). Results of prophylaxis duration, timing, antibiotics used for prophylaxis were also expressed as percentages. The proportions of appendectomy represent prevalence rates accompanied by their $95 \%$ confidence intervals (CIs) for percentages. The study protocol was accepted by the local ethics committee.

\section{RESULTS}

Table 1 shows patients' demographic data. There were 30

Table 2: Appendicitis characteristics

\begin{tabular}{|c|c|c|c|c|}
\hline \multirow[t]{2}{*}{ Type of appendicitis } & \multicolumn{2}{|c|}{ July/August } & \multicolumn{2}{|c|}{ November/December } \\
\hline & $\mathrm{N}$ of patients & $\%$ & $\mathrm{~N}$ of patients & $\%$ \\
\hline $\begin{array}{l}\text { Total } \mathrm{N} \text { of patients with perforated or non- } \\
\text { perforated appendicitis }\end{array}$ & 30 & 100 & 38 & 100 \\
\hline Perforated appendicitis & 4 & 13.3 & 11 & 28.9 \\
\hline Non-perforated & 26 & 86.7 & 27 & 71.1 \\
\hline $\begin{array}{l}\text { Total } \mathrm{N} \text { of patients with phlegmonous or } \\
\text { gangrenous appendicitis }\end{array}$ & 30 & 100 & 38 & 100 \\
\hline Phlegmonous appendicitis & 19 & 63.3 & 17 & 44.7 \\
\hline Gangrenous appendicitis & 11 & 36.7 & 21 & 55.3 \\
\hline
\end{tabular}


patients with acute appendicitis in July/August: mean \pm SD (age): $9.8 \pm 3.6$, skewness 0.3 and kurtosis -1.5 and 38 patients in November/December: mean \pm SD (age): $11.7 \pm 3.7$, skewness 0.2 and kurtosis -1.2. $2 / 30(6.7 \%)$ patients in July/August and 5/38 (13.2\%) in November/ December were treated with ampicillin and gentamicin (without surgery) and 1 of them in November/December had periappendicular infiltrate. 4/30 (13.3\%) patients had peritonitis and/or periapendicular infiltrate. 5/28 (17.9\%) patients, who had surgery, did not receive antibiotics in July/August and 2/33 (6.1\%) in November/December. Table 2 shows appendicitis characteristics. Duration of prophylaxis and time, when antimicrobial agent was started, is shown in the Table 3. The most often used antibiotic combination was ampicillin with gentamicin: 9/23 (39.1\%) patients with surgery in July/August and 16/31
$(51.6 \%)$ November/December received this combination. Single antibiotics and antibiotic combinations used for prophylaxis are shown in the Table 4. Only $1 / 31$ (3.2\%) patient received antibiotics (cefotaxime) in accordance with the guidelines in November/December. In all cases antibiotics were used intravenously.

\section{DISCUSSION}

This study provides a comparison of antibiotic use before and after the introduction of the hospital guidelines for surgical prophylaxis. Most of studies analyse adherence to hospital guidelines prospectively ${ }^{12}$ or retrospectively, ${ }^{13}$ but not the situation before and after the introduction of them. ${ }^{14}$ In the Dutch study, where adherence to

Table 3: Prophylaxis characteristics

\begin{tabular}{|c|c|c|c|c|}
\hline \multirow{2}{*}{$\begin{array}{l}\text { Duration and timing of } \\
\text { prophylaxis }\end{array}$} & \multicolumn{2}{|c|}{ July/August } & \multicolumn{2}{|c|}{ November/December } \\
\hline & $\mathrm{N}$ of patients & $\%$ & $\mathrm{~N}$ of patients & $\%$ \\
\hline $\begin{array}{l}\text { Total } \mathrm{N} \text { of patients on } \\
\text { antibiotics (with surgery) }\end{array}$ & 23 & 100 & 31 & 100 \\
\hline \multicolumn{5}{|l|}{ Duration of prophylaxis } \\
\hline 1 dose & 2 & 8.7 & 4 & 12.9 \\
\hline Multiple doses within $24 \mathrm{~h}$ & 1 & 4.3 & 2 & 6.5 \\
\hline$>1$ day & 20 & 87.0 & 25 & 80.6 \\
\hline \multicolumn{5}{|l|}{ Timing } \\
\hline Too early & 7 & 30.4 & 9 & 29.0 \\
\hline On time & 2 & 8.7 & 8 & 25.8 \\
\hline Too late & 12 & 52.2 & 14 & 45.2 \\
\hline $\begin{array}{l}\text { No information about time } \\
\text { in patient's records }\end{array}$ & 2 & 8.7 & 0 & 0 \\
\hline
\end{tabular}

Table 4: Antibiotics used for surgical prophylaxis

\begin{tabular}{|c|c|c|c|c|}
\hline \multirow{2}{*}{$\begin{array}{l}\text { Antibiotics used for } \\
\text { prophylaxis / Type of } \\
\text { prophylaxis }\end{array}$} & \multicolumn{2}{|c|}{ July/August } & \multicolumn{2}{|c|}{ November/December } \\
\hline & No of patients & $\%$ & No of patients & $\%$ \\
\hline $\begin{array}{l}\text { Total } \mathrm{N} \text { of patients on } \\
\text { antibiotics (with surgery) }\end{array}$ & 23 & & 31 & \\
\hline Mono antibiotic prophylaxis & 6 & 26.1 & 10 & 32.3 \\
\hline $\begin{array}{l}\text { Combination of antibiotics } \\
\text { used for prophylaxis }\end{array}$ & 17 & 73.9 & 21 & 67.7 \\
\hline \multicolumn{5}{|c|}{ Antibiotics used for mono prophylaxis } \\
\hline Cefazolin & 1 & 16.7 & 0 & 0 \\
\hline Ampicillin & 2 & 33.3 & 3 & 30.0 \\
\hline Ceftriaxone & 3 & 50.0 & 3 & 30.0 \\
\hline Cefuroxime & 0 & 0 & 3 & 30.0 \\
\hline Cefotaxime & 0 & 0 & 1 & 10.0 \\
\hline \multicolumn{5}{|c|}{ Combination of antibiotics used for prophylaxis } \\
\hline Ampicillin + gentamicin & 9 & 52.9 & 16 & 76.2 \\
\hline Ampicillin + metronidazole & 1 & 5.9 & 1 & 4.8 \\
\hline $\begin{array}{l}\text { Cetriaxone }+ \\
\text { metronidazole }\end{array}$ & 7 & 41.2 & 3 & 14.3 \\
\hline Cefazolin + gentamicin & 0 & 0 & 1 & 4.8 \\
\hline
\end{tabular}


the hospital guidelines was analysed, one of problems was surgeons' disagreement with the local guidelines produced by the hospital committees. ${ }^{15}$ The present study demonstrates that, although the guidelines were discussed and accepted by surgeons' they did not follow them. One of the problems, that we have identified, was unnecessary prolonged prophylaxis. The length of prophylaxis was only slightly decreased after the introduction of the guidelines. These results are similar to the other studies, where the inappropriate length of antibiotic use for surgical prophylaxis was reported. ${ }^{9,10,16}$ Another problem was correct timing of the first dose. Although it has improved after the introduction of the hospital guidelines, there were still many cases, when the first dose was started too late. Logistical constraints could be important barriers to adherence to the guidelines for timing. We identified the lack of communication between anaesthesiologists, surgeons and nurses in surgical wards, e.g., who is responsible for the administration of antibiotics before the operation and what happens if the operation is delayed for some time due to different reasons. These results are similar to the other studies where the problem of correct timing is identified. ${ }^{17}$ Antibiotic prophylaxis is recommended for appendicitis by both local and international guidelines. ${ }^{18,19}$ In this study we did not analyse the development of the surgical site infection: whether there is any correlation between patients, who did not receive antibiotic prophylaxis on time, and the development of the surgical site infection. According to the literature, the development of the surgical site infection is possible in $9-30 \%$ of patients with uncomplicated appendicitis, who do not receive prophylactic antimicrobials. ${ }^{18}$ After the introduction of the guidelines there was only one case when correct choice of antibiotic was made. Probably a critical appraisal of the content of the guidelines is needed. Most surgeons still preferred to use ampicillin plus gentamicin instead of cefotaxime. There is no consensus in literature regarding the topic - which antimicrobial agent or combination of agents would be superior to other antibiotics in the prophylaxis of postappendectomy infectious complications. The correct choice for SSI prophylaxis would be any single agent or combination of agents that provides adequate gram-negative and anaerobic coverage. ${ }^{18}$ Therefore some other aspects, e.g., financial also should be analysed. Bansal et al. analysed in a prospective consecutive cohort study preoperative antimicrobial prophylaxis versus no prophylaxis in children undergoing urgent appendectomy. Authors conclude that prophylaxis with metronidazole did not reduce postoperative infectious complications. ${ }^{20}$ Perhaps it is because metronidazole alone did not provide both gram-negative and anaerobic coverage.
Surgical treatment was not in the focus of this article but there is also a need for improvement, e.g., in most cases parenteral antibiotics were used despite evidence supporting switch over from intravenous to oral therapy. ${ }^{21}$

Our study has several limitations. First of all, perhaps the introduction period of two months was too short for the surgeons to change their attitudes. But, as it was mentioned before, the guidelines were discussed with the surgeons before they were officially approved and there was no disagreement between the surgeons and the antibiotic committee. Secondly, adherence to the guidelines was analysed only in the acute appendicitis. It is possible that situation with the acceptance of the guidelines is better in other surgical specialities. But we decided to start with the evaluation of antibiotic prophylaxis in acute appendicitis, as it is one of the most common reasons for surgery. Different tools are needed to improve antibiotic use in the hospital. According to Wickens et al. the role of the clinical pharmacist is to promote the evidence-based medicine and cost-effective prescribing. Clinical pharmacists may help to optimize and promote rational use of antibiotics in order to reduce their inappropriate use, and that may help to prevent the development and spread of resistance. ${ }^{22} \mathrm{It}$ is pharmacists' responsibility to promote rational use of medicines and evidence-based pharmacy. ${ }^{23}$ Although there are some data/information suggesting that restrictive methods (e.g., formulary restrictions, regular reviews by pharmacists in wards) are more effective than educational interventions, ${ }^{24}$ there is a need for both: the local guidelines with restriction measures as well as educational programmes. ${ }^{25}$

\section{CONCLUSION}

Although some positive trends were observed, the antibiotic treatment guidelines did not have a major impact on antibiotic use, despite the fact that the guidelines were discussed and accepted by the surgeons and there were two month introduction period. New ways of promoting adherence to the guidelines and appropriate antibiotic use need to be explored.

\section{CONFLICT OF INTEREST}

Both authors have nothing to declare.

\section{REFERENCES}

1. Daskalakis $K$, Juhlin C, Påhlman L. The use of pre- or postoperative antibiotics in surgery for appendicitis: a systematic review. Scand J. Surg. 2014; 103(1):14-20. 2. Ohmann C, Franke C, Kraemer M, Yang Q. Neues zur Epidemiologie der akuten Appendizitis. Der Chirurg. 2002;73(8): 769-76.

3. Aarabi S, Sidhwa F, Riehle KJ, Chen Q, Mooney DP. Pediatric appendicitis in New England: epidemiology and outcomes. J. Pediatr Surg. 2011; 46(6):1106-14.

4. Spyridis N, Sharland M. The European Union Antibiotic Awareness Day: the 
Paediatric Perspective. Arch Dis Child. 2008; 93(11): 909-10.

5. Gerber JS, Newland JG, Coffin SE, Hall M, Thurm C, Prasad PA, et al. Variability in Antibiotic Use at Children's Hospitals. Pediatrics. 2010; 126(6): 1067-73.

6. EUR-lex [homepage on the Internet]. Council of the European Union: Council Recommendation of 15 November 2001 on the prudent use of antimicrobial agents in human medicine (2002/77/EC). Official Journal of the European Communities L34 2002 [updated 2014 March 20; cited 2014 May 15]. Available from: http://eurlex.europa.eu/LexUriServ/LexUriServ.do?uri=OJ:L:2002:034:0 013:0016:EN:PDF

7. Tourmousoglou CE, Yiannakopoulou E Ch, Kalapothaki V, Bramis JSt, Papadopoulos J. Adherence to guidelines for antibiotic prophylaxis in general surgery: a critical appraisal. J. Antimicrob Chemother. 2008; 61(1): 214-8.

8. Hansen S, Sohr D, Piening B, Pena Diaz L, Gropmann A, Leistner R, et al. Antibiotic usage in German hospitals: results of the second national prevalence study. J Antimicrob Chemother. 2013; 68: 2934-9.

9. Rangel SJ, Fung M, Graham DA, Ma L, Nelson CP, Sandora TJ. Recent trends in the use of antibiotic prophylaxis in pediatric surgery. J. Pediatr Surg. 2011; 46(2): 366-71.

10. Versporten A, Sharland M, Bielicki J, Drapier N, Vankerckhoven V, Goossens $\mathrm{H}$, for the ARPEC Project Group Members. The Antibiotic Resistance and Prescribing in European Children Project. A Neonatal and Pediatric Antimicrobial Web-based Point Prevalence Survey in 73 Hospitals Worldwide. Pediatr Infect Dis J. 2013; 32(6): e242-e53.

11. Allerberger F, Gareis R, Jindrak V, Struelens MJ. Antimicrobial stewardship implementation in the EU: the way forward. Expert Rev Anti Infect Ther. 2009; 7(10): 1175-83

12. Friedman ND, Styles K, Gray AM, Low J, Athan E. Compliance with surgical antibiotic prophylaxis at an Australian teaching hospital. Am J. Infect Control. 2013; 41(1): 71-4

13. Voit SB, Todd JK, Nelson B, Nyquist AC. Electronic surveillance system for monitoring surgical antimicrobial prophylaxis. Pediatrics. 2005; 116(6): 1317-22.

14. Kim ES, Park SW, Lee CS, Gyung Kwak Y, Moon C, Kim BN. Impact of a national hospital evaluation program using clinical performance indicators on the use of surgical antibiotic prophylaxis in Korea. Int J. Infect Dis. 2012; 16(3): e187-e92.

15. Van Kasteren ME, Kullberg BJ, de Boer AS, Mintjes-de Groot J, Gyssens IC Adherence to local hospital guidelines for surgical antimicrobial prophylaxis: a multicentre audit in Dutch hospitals. J. Antimicrob Chemother. 2003; 51(6) 1389-96.

16. Ceyhan M, Yildirim I, Ecevit C, Aydogan A, Ornek A, Salman N, et al. Inappropriate antimicrobial use in Turkish pediatric hospitals: A multicenter point prevalence survey. Int J Infect Dis. 2010; 14(1): e55-e61.

17. Burke JP. Maximizing Appropriate Antibiotic Prophylaxis for Surgical Patients: An Update from LDS Hospital, Salt Lake City. Clin Infect Dis. 2001; 33(2) S78-S83.

18. Bratzler DW, Dellinger EP, Olsen KM, Perl TM, Auwaerter PG, Bolon MK, et al. Clinical practice guidelines for antimicrobial prophylaxis in surgery. Surg Infect (Larchmt). 2013; 14(1): 73-156.

19. Sign.ac.uk [homepage on the Internet]. Scottish Intercollegiate Guidelines Network: Antibiotic prophylaxis in surgery [updated 2014 June 6; cited 2014 June 12]. Available from: http://www.sign.ac.uk/pdf/sign104.pdf

20. Bansal V, Altermatt S, Nadal D, Berger C. Lack of benefit of preoperative antimicrobial prophylaxis in children with acute appendicitis: a prospective cohort study. Infection. 2012; 40(6): 635-41.

21. Cyriac JM, James E. Switch over from intravenous to oral therapy: A concise overview. J. Pharmacol Pharmacother. 2014; 5(2): 83.

22. Wickens HJ, Farrell S, Ashiru-Oredope DAI, Jacklin A, Holmes A. The increasing role of pharmacists in antimicrobial stewardship in English hospitals. J Antimicrob Chemother. 2013; 68(11): 2675-81.

23. Toklu HZ, Hussain A. The changing face of pharmacy practice and the need for a new model of pharmacy education. J Young Pharm. 2013; 5(2): 38-40.

24. Davey P, Brown E, Charani E, Fenelon L, Gould IM, Holmes A, et al Interventions to improve antibiotic prescribing practices for hospital inpatients. Cochrane Database Syst Rev. CD003543. 2013; Apr 30;4:CD003543. doi: 10.1002/14651858.CD003543.pub3.

25. Dachs R. Interventions to improve antibiotic prescribing practices for hospital inpatients. Am Fam Physician. 2008; 77(5): 618-9. 